\title{
Vector bionomics and malaria transmission in the Upper Orinoco River, Southern Venezuela
}

\author{
Magda Magris, Yasmin Rubio-Palis ${ }^{+}$, Cristóbal Menares, Leopoldo Villegas
}

\author{
Ministerio de Salud, Maracay, Venezuela
}

\begin{abstract}
A longitudinal epidemiological and entomological study was carried out in Ocamo, Upper Orinoco River, between January 1994 and February 1995 to understand the dynamics of malaria transmission in this area. Malaria transmission occurs throughout the year with a peak in June at the beginning of the rainy season. The Annual Parasite Index was 1,279 per 1,000 populations at risk. Plasmodium falciparum infections accounted for $64 \%$ of all infections, P. vivax for $28 \%$, and P. malariae for $4 \%$. Mixed P. falciparum/P. vivax infections were diagnosed in 15 people representing $4 \%$ of total cases. Children under 10 years accounted for $58 \%$ of the cases; the risk for malaria in this age group was 77\% higher than for those in the greater than 50 years age group. Anopheles darlingi was the predominant anopheline species landing on humans indoors with a biting peak between midnight and dawn. A significant positive correlation was found between malaria monthly incidence and mean number of An. darlingi caught. There was not a significant relationship between mean number of An. darlingi and rainfall or between incidence and rainfall. A total of 7295 anophelines were assayed by ELISA for detection of Plasmodium circumsporozoite (CS) protein. Only An. darlingi (55) was positive for CS proteins of P. falciparum $(0.42 \%)$, P. malariae $(0.25 \%)$, and P. vivax-247 $(0.1 \%)$. The overall estimated entomological inoculation rate was 129 positive bites/person/year. The present study was the first longitudinal entomological and epidemiological study conducted in this area and set up the basic ground for subsequent intervention with insecticide-treated nets.
\end{abstract}

Key words: Plasmodium falciparum - Plasmodium vivax - Plasmodium malariae - malaria incidence - Anopheles darlingi biting activity - sporozoite rate - entomological inoculation rate - Venezuela

Malaria is a public health problem in some areas of Venezuela, particularly in the state of Amazonas and among Amerindians of the Yanomami ethnic group who inhabit the Upper Orinoco River in the South of Venezuela near the border with Brazil (Fig. 1) (MSAS 1995, MS 2005). Cross-sectional surveys carried out in this area during 1991 determined that malaria was hyperendemic based on parasitological, clinical, and immunulogical parameters (Marcano et al. 2004).

Anopheles (Nyssorhynchus) darlingi Root is considered the most efficient vector of malaria parasites throughout its range of distribution, especially in the Amazon basin because of its high degree of anthropophilism and susceptibility to infection with Plasmodium falciparum, $P$. vivax, and P. malariae (Rachou 1958, Deane 1986, 1989, Rozendaal 1990, Arruda et al. 1986, Lourenço-de-Oliveira et al. 1989, Klein et al. 1991a, b, Tadei et al. 1998, Rubio-Palis 2000, FloresMendoza et al. 2004, Grieco et al. 2005, Póvoa et al. 2006). In the southern states of Amazonas and Bolívar, in Venezuela, An. darlingi has been implicated as the principal vector and is responsible for $84 \%$ of total cases reported in the country (DER 1998, MS 2005). Never-

Financial support: Convenio Antimalárico CVG/MSAS/Gobernación estado Amazonas, the Pan American Health Organization ${ }^{+}$Corresponding author: rubiopalis@yahoo.com

Received 30 October 2006

Accepted 8 May 2007 theless, limited information exists on this species regarding seasonal abundance, biting rate, biting activity, relative abundance in relation to other species, and infection rates with malaria parasites. Although some epidemiological studies were conducted in the Upper Orinoco River, there are no longitudinal entomological studies directed toward the understanding of the dynamics of malaria transmission.

Vector control measures applied in this area have been sporadic, using DDT or fenitrothion to spray dwellings with incomplete or no walls, without the basic knowledge on the bionomics of An. darlingi in this particular remote area.

At present the malaria control program is confronted by several technical and administrative difficulties that reduce the effectiveness of the program. In Amazonas, and in particular in the Upper Orinoco River, the control methods applied have failed because of several factors, such as: (a) geographic situation, with difficult access; (b) socio-cultural characteristics of the Yanomami population (Lizot 1988,1998), with frequent migration, belief in supernatural etiology of the disease, intra-ethnic conflicts and housing with incomplete or no walls; (c) circulation of $P$. falciparum strains with multiple drug resistance (Magris 1996, Riggione et al. 1998); and (d) biting and resting behavior of the principal vector, $A n$. darlingi (Rubio-Palis 1995).

To understand the dynamics of malaria transmission in the Upper Orinoco River and suggest control measures, a longitudinal epidemiological and entomological study was carried out in Ocamo between January 1994 and February 1995. 


\section{MATERIALS AND METHODS}

Study area - The study was carried out over a period of 14 months (January 1994 - February 1995) in the location of Ocamo $\left(02^{\circ} 50^{\prime} \mathrm{N}, 65^{\circ} 14^{\prime} \mathrm{W}\right)$ in the state of Amazonas, Southern Venezuela (Fig. 1). Ocamo comprises nine villages or "shabonos" (Santa Maria de los Guaicas-Ocamo, Boca Padamo, Dayaritheri, Lechoza, Kashora, Tumba, Shashana, Yohope, and San Benito) located along the Orinoco and Ocamo rivers, the distance between villages being about $2 \mathrm{~km}$. The villages are about $116 \mathrm{~m}$ above sea level. The mean annual temperature was $24^{\circ} \mathrm{C}$ and $80 \%$ relative humidity, with an annual rainfall of $2487 \mathrm{~mm}$ (MARNR 1995). The area is classified as lowland forest (Huber 1995) and interior evergreen and semi-evergreen forest (Osborn et al. 2004). From the eco-epidemiological point of view the area has been classified as lowland interior forest malaria (Rubio-Palis \& Zimmerman 1997).

In Santa Maria de los Guaicas (Ocamo), the main identified anopheline larval habitats were two permanent large lagoons located about $400 \mathrm{~m}$ from dwellings, confirmed by subsequent studies (Rejmánková et al. 1999, Rubio-Palis et al. 2005). The population is Amerindian of the Yanomami ethnic group. The type of houses varies among "shabonos" from a large circular shelter with no walls and thatched roof to houses with mud walls and corrugated iron roofs. Members of the same family group hang their hammocks around a fire, and there may be up to eight family groups (eight fires) under the same roof. The fire burns day and night, so that houses with walls are very smoky.

The "shabonos" have not been subject to insecticide spraying since 1993.

Demographic surveillance - A population census was conducted during June 1994. In each village, dwellings were given a code number and numbers of fires or family groups recorded. In each family group every resident's Yanomami and/or "nape" (foreign) name, approximate age and sex were recorded. All births and deaths occurring during the study were recorded.

Malaria diagnosis and treatment - Under the Primary Health Care (PHC) system, active and passive case detection was routinely conducted in the villages. The active case detection was made twice a month in each "shabono". Thick and thin blood films were routinely taken from a person reporting fever at the moment of the visit or during the previous three days and children under six years of age with diarrhea or vomiting. After fixation with methanol, films were stained with Giemsa and observed by the authors. One hundred high-power fields of each thick film were examined and the parasite species determined. Confirmed malaria cases were treated according to the drug schedule approved by the National Malaria Control Program for the Upper Orinoco region: patients with uncomplicated $P$. falciparum malaria were given $25 \mathrm{mg} / \mathrm{kg}$ pyrimethamine-sulfadoxine-

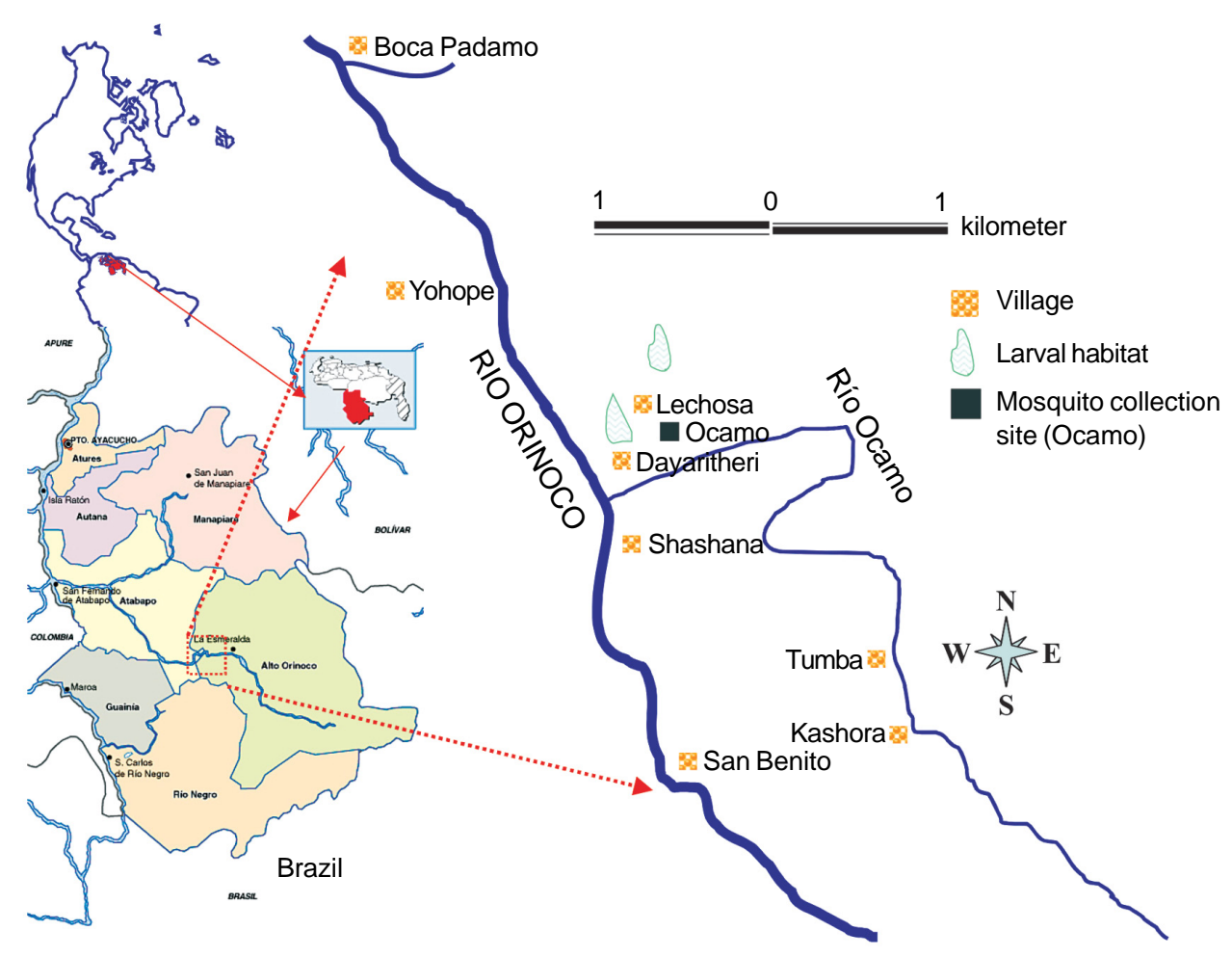

Fig. 1: location of the study area in the Upper Orinoco River region. 
mefloquine, the dose calculation was based on the concentration of mefloquine; severe and complicated $P$. falciparum malaria cases were treated with a $20 \mathrm{mg} / \mathrm{kg}$ initial dose of quinine and subsequent doses of $10 \mathrm{mg} /$ $\mathrm{kg}, 10 \mathrm{mg}$ every $8 \mathrm{~h}$ for seven days; patients with $P$. vivax were given $25 \mathrm{mg} / \mathrm{kg}$ of chloroquine divided in three doses $(10 \mathrm{mg} / \mathrm{kg}, 10 \mathrm{mg} / \mathrm{kg}$, and $5 \mathrm{mg} / \mathrm{kg}$ ) plus primaquine $0.5 \mathrm{mg} / \mathrm{kg}$ for five days. $P$. malariae cases were treated with $25 \mathrm{mg} / \mathrm{kg}$ of chloroquine divided in three doses. Primaquine and pyrimethamine-sulfadoxinemefloquine was not given to infants and pregnant women. The later were treated with quinine. A new episode of slide-positive malaria was considered to be a relapse or recrudescence if it occurred within six months ( $P$. vivax), or one month ( $P$. falciparum) after a previous episode of acute malaria diagnosed during the study.

Malariometric parameters considered were: annual parasite index (API = malaria cases divided by the population under surveillance multiply by 1000), slide-positive rate $(\mathrm{SPR}=$ percentage of slides positives for malaria), and slide-positive percentage by species (percentage of parasite of each Plasmodium species). The association between malaria cases and age group was determined using a logistical regression model in Stata (version 7.0; Stata Corporation, College Station, TX, US). The age group of children under 10 years was considered as the base line.

Mosquito collections - Human landing catches of anopheline mosquitoes were carried out inside selected dwellings in the village of Santa María de los Guaicas. The houses had thatched roofs and incomplete mud walls. Collectors worked in pairs catching with a mouth aspirator all mosquitoes landing on a person resting inside his hammock, from 19:00 to 06:00 h, five to eight nights per month for 13 months between February 1994 and February 1995. Captured mosquitoes were placed in paper cups, a new cup being started every hour. After identification, mosquitoes were counted and stored over silica gel at room temperature until assayed by enzymelinked immunosorbent assay (ELISA). Climatological data were obtain from the Ministerio del Ambiente y los Recursos Naturales Renovables (MARNR) weather station located in Santa Maria de lo Guaicas.

Mosquito preparation and ELISA - Abdomens, wings, and legs of dried female Anopheles were removed to reduce the risk of detection of circumsporozoite (CS) antigen from parts of the body other than the salivary glands. Mosquitoes of the same species and date of collection were combined in pools of up to 10 ; this criteria is accepted in areas where infections rates are less than $1 \%$, because it is highly unlikely that more than one mosquito is infected in one pool. The ELISA protocol described by Wirtz et al. $(1987,1992)$ was followed to detect CS proteins of $P$. falciparum, $P$. vivax-210, and 247 polymorphs and $P$. malariae. Positive and negative controls were run on every ELISA test plate. Positive controls consisted of $0.1 \mathrm{ng}$ of recombinant $P$. falciparum CS protein, $0.04 \mathrm{ng}$ of $P$. vivax-210 CS protein, $1.25 \mathrm{ng}$ of $P$. vivax-247 CS protein, and $250 \mathrm{ng}$ of P. malariae CS protein. Laboratory-raised An. albi- manus males were used for negative controls in all assays. All readings were analyzed at $405 \mathrm{~nm}$ recorded with a Molecular Devices ELISA plate reader 30 min after the addition of the ABTS substrate. Samples were considered positive upon confirmation if absorbance values exceeded two times the mean of seven negative controls.

\section{RESULTS}

Demographic surveillance - A total of 297 people were registered; 160 (54\%) were males and 137 (46\%) females, comprising 58 family groups, e.i. 58 fires. Ninety eight percent (203) of the population was located in Santa Maria de los Guaicas-Ocamo. In general, the population was young, with $65.6 \%$ of people under 30 years of age. The composition of the population was as follows: children under 10 years of age accounted for $30 \%$ (86), the group between 10 and 19 for only $15.8 \%$ (47), while the group between 20 and 29 years of age for $20.9 \%$ (62), the group 30-39 for $17.5 \%$ (52), 40-49 for $12.1 \%$ (36) and a small portion $(4.5 \%)$ were over 50 years of age. This age structure is typical of Amerindian populations (INE, 1993, 2001).

Malaria morbidity and mortality - During the study 884 blood slides were examined and 380 (43\%) new cases of malaria were diagnosed and treated, with an API of 1279.46 per 1000 population. Children under 10 years of age accounted for $58.4 \%$ (222) of the cases (Fig. 2). Significantly $(\mathrm{P}<0.001)$, more cases $(205)$ were diagnosed in males than in females (175). The risk for malaria by age group, estimated by logistic regression analysis considering the age group under 10 years (yrs) as a base line, was: $10-19$ yrs = OR: 0.55 , 95\% CI: $0.35-$ 0.84 ( $\mathrm{P}<0.001) ; 20-50$ yrs = R: $0.46,95 \%$ CI: $0.34-$ $0.61(\mathrm{P}<0.0001)$; over 50 yrs = OR: $0.22,95 \% \mathrm{CI}$ : 0.08-0.61 $(\mathrm{P}<0.01)$. These results demonstrated that the Odd Ratios (OR) for malaria cases decreases with increasing age; persons over 50 years had $77 \%$ less malaria than children under 10 years old (Fig. 2). The monthly incidence is shown in Fig. 3. P. falciparum infections accounted for $63.8 \%$ of all infection, $P$. vivax $27.7 \%$, and P. malariae $4.5 \%$ (Fig. 4). Mixed P. falci-

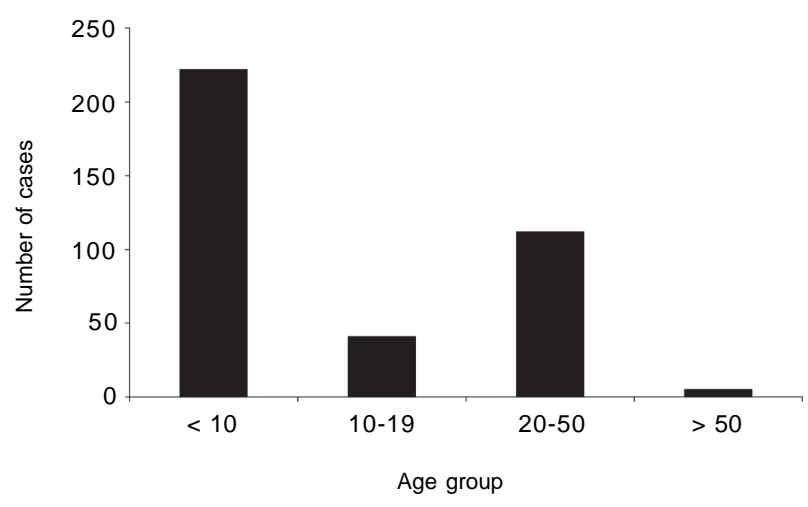

Fig. 2: number of malaria cases by age group recorded during 1994 in Ocamo, Upper Orinoco River, Venezuela. 


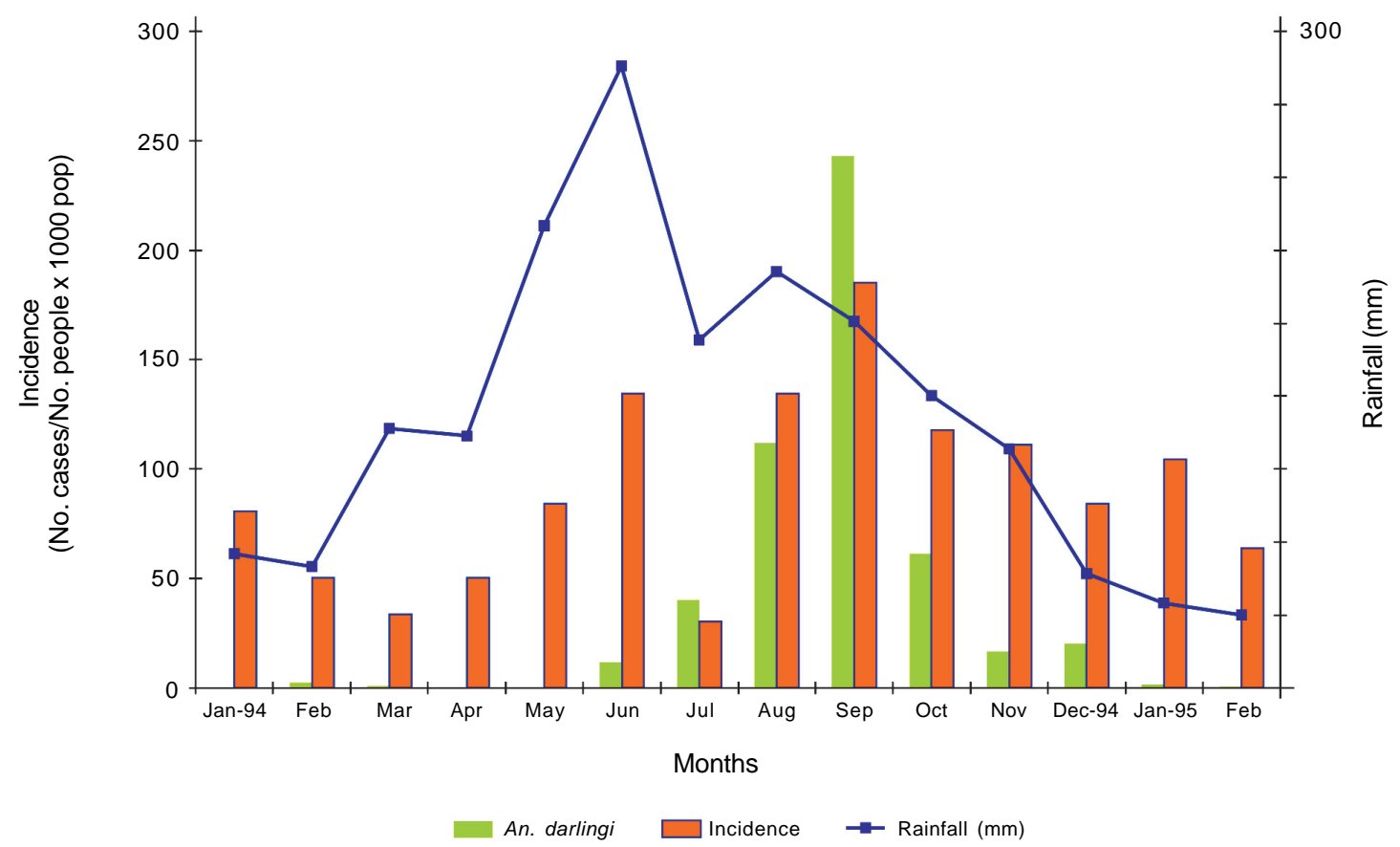

Fig. 3: monthly malaria incidence, mean number of Anopheles darlingi caught, and rainfall (mm) in Ocamo, Upper Orinoco River. January 1994February 1995.

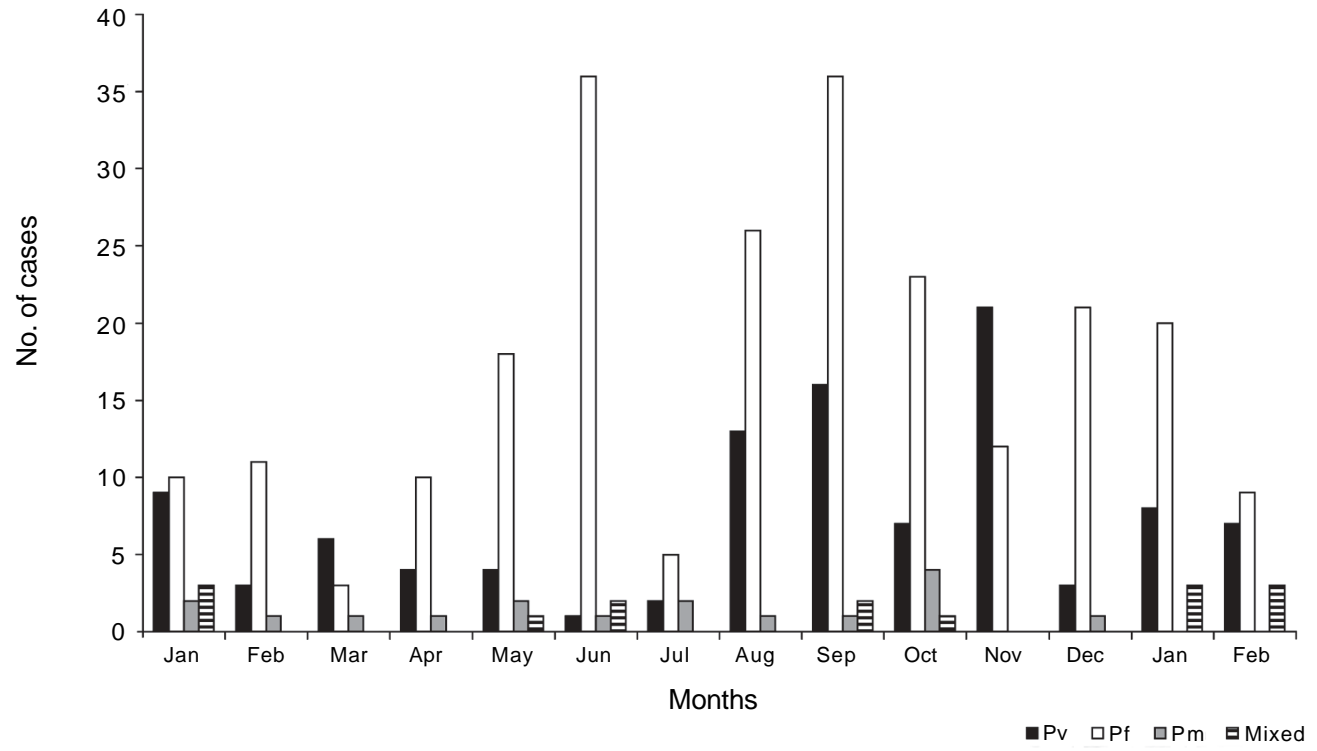

Fig. 4: number of cases diagnosed monthly by parasite species between January 1994 and February 1995.

parum/P. vivax infections were diagnosed in 15 people representing $4 \%$ of total cases. During June, $P$. falciparum infections represented $90 \%$ of total cases reported (Fig. 4). During the study, three certified deaths caused by malaria were reported in children less than 10 years of age. Correlation of the malaria monthly incidence on rainfall was not significant $(\mathrm{p}=0.2537)$.
Anopheline abundance and seasonality - A total of 7784 female anopheline mosquitoes were collected over a total of 70 all-night catches indoors. The most abundant species was An. darlingi (7196), comprising 92.4\% of the total collected; other species collected were $A n$. braziliensis (7.4\%), An. oswaldoi (0.2\%), and An. mediopunctatus $(0.01 \%)$. An. darlingi showed a marked 
seasonality. It almost disappeared between April and May and was most abundant between July and October with a peak during September (Fig. 3). During the study, the wettest month was June 1994 (426.2 mm of rainfall) and the driest was February 1995 (50.1 mm); according to criteria used to determine the onset of the rainy season - when monthly rainfall is above $60 \mathrm{~mm}$ (Koeppen 1948, Goldbrunner 1984) - during 1994 there was no dry season, only months with less rain (January and February); the dry season started in January 1995 (58.2 mm) (Fig. 3). Regression of the log-transformed mean number of An. darlingi caught on mean and maximum river levels were not significant $(\mathrm{P}>0.05)$, while the regression on maximum river level with 1 month lag was sig- nificant $(\mathrm{P}=0.03)$, e.i. the abundance of $A n$. darlingi peaked one month after the maximum river level (Fig. 5). To check whether An. darlingi abundance was related to rainfall, a similar regression analysis was made. It was found that the relationship between rainfall in the month of collection or in the previous 1, 2 or 3 months and the mean number of this species was not significant ( $p>0.5$ ). Nevertheless, the relationship between mean number of $A n$. darlingi and monthly malaria incidence was significant $(\mathrm{P}=0.0059)$.

An. darlingi biting behavior - Fig. 6 shows that An. darlingi is active throughout the night indoors, with a gradual increase towards midnight when a plateau is reached that lasts until dawn.

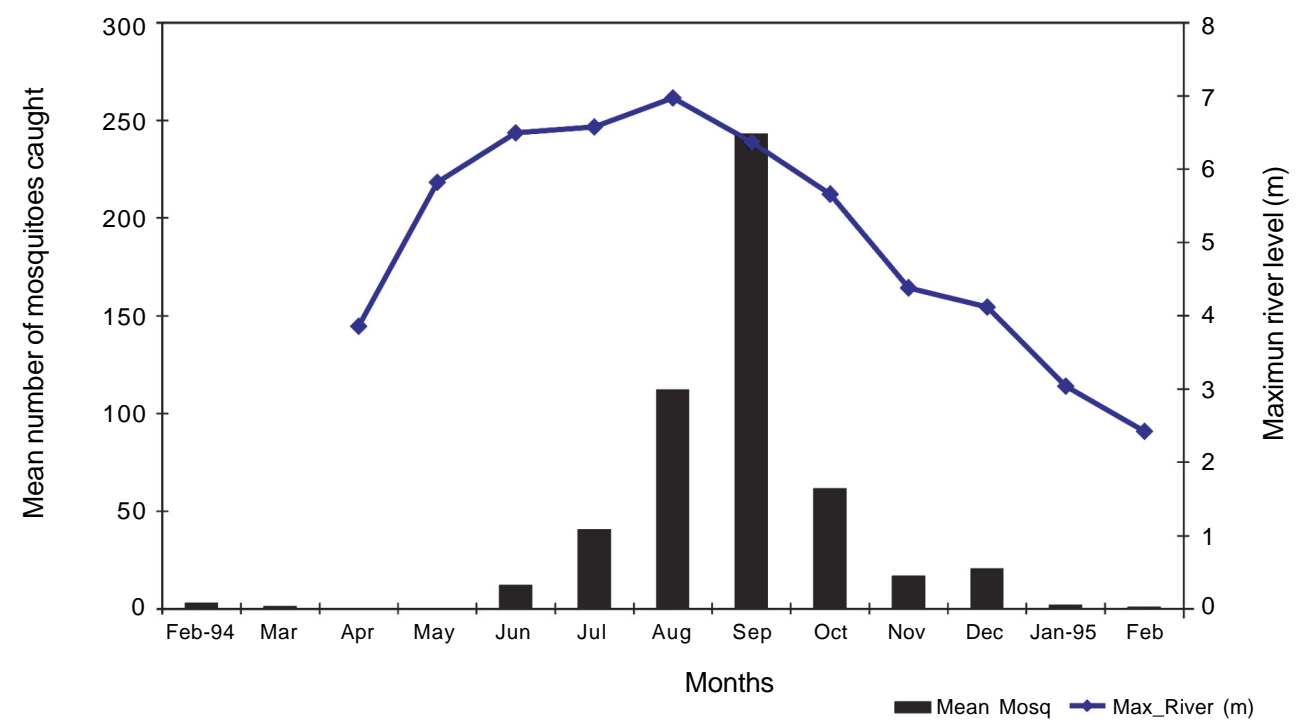

Fig. 5: mean number of Anopheles darlingi caught monthly and maximum river level (m).

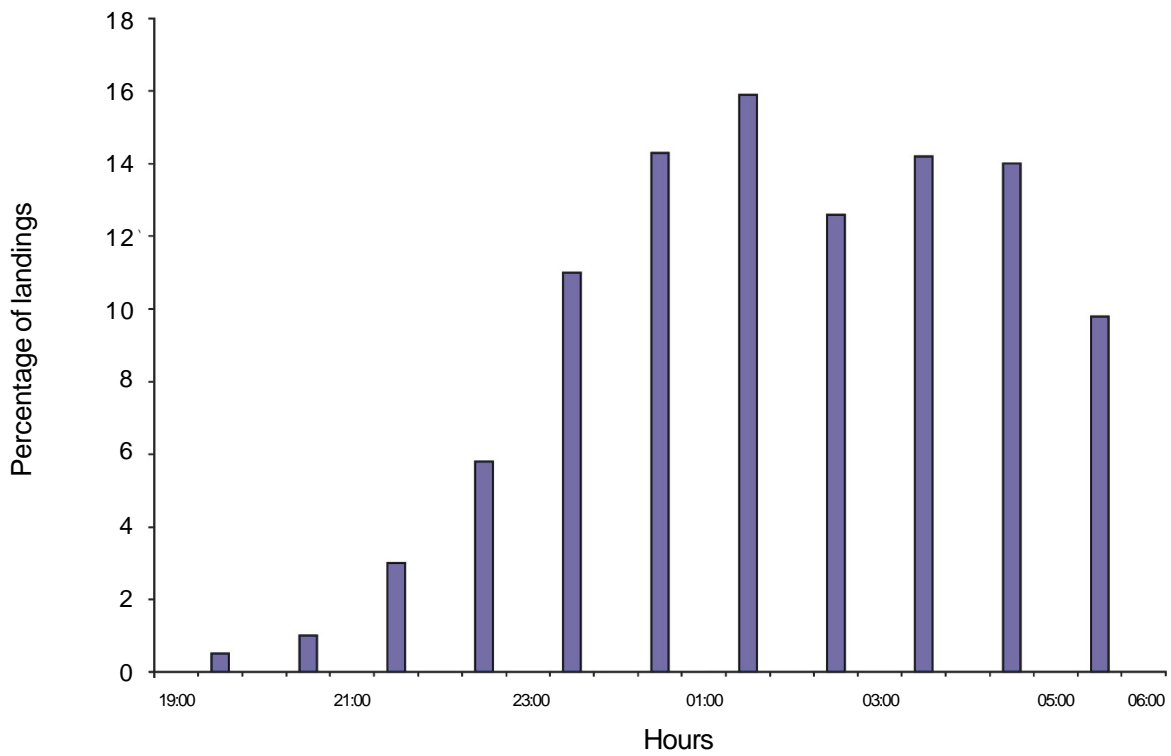

Fig. 6: biting activity of Anopheles darlingi in the study area. 
TABLE

Malaria circumsporozoite positivity rates [number of circumsporozoite (CS) positive mosquito ${ }^{a}$ found (55), divided by the total number of mosquitoes tested (7196)] of Anopheles darlingi and entomological inoculation rate (EIR) in Ocamo, February 1994-1995

\begin{tabular}{lcccc}
\hline CS antigen & $\begin{array}{c}\text { Mosquitoes } \\
\text { positives }(\mathrm{n})\end{array}$ & $\begin{array}{l}\text { Positive } \\
\text { rate }(\%)\end{array}$ & $\begin{array}{c}\text { 95\% Confidence } \\
\text { Intervals }(\%)\end{array}$ & EIR \\
\hline Plasmodium falciparum & 30 & 0.417 & $0.268-0.568$ & 70.08 \\
P. vivax-210 & 0 & 0 & $0-0.051$ & 0 \\
$P$. vivax-247 & 7 & 0.097 & $0.039-0.200$ & 16.45 \\
$P$. malariae & 18 & 0.250 & $0.136-0364$ & 42.05 \\
\hline
\end{tabular}

$a$ : number of mosquitoes equivalent to number of pools tested.

An. darlingi man-biting rate - The number of An. darlingi collected per night varied from zero during May to 1265 during September, two months after the peak of rains. During the study 3224 An. darlingi were caught per person in 70 nights; it was estimated that the mean manbiting rate was 46.06 bites/person/night, i.e. in one year a person might receive in this area $16811 \mathrm{An}$. darlingi bites.

Sporozoite rate and entomological inoculation rate - A total of 7295 anophelines were tested: 7196 (98.5\%) An. darlingi and 99 An. braziliensis. Results from the sporozoite ELISAs for Ocamo are shown in the Table. Only An. darlingi was positive for CS proteins of Plasmodium spp. The over all CS protein rate was $0.764 \%$ [0.42\% P. falciparum (95\% CI: $0.268-0.568 \%$ ), $0.25 \%$ P. malariae (95\% CI: 0.136-0.364\%), and $0.1 \%$ P. vivax247 (95\% CI: 0.039-0.20\%)] in 55 An. darlingi (equivalent to 55 pools) collected between July and November 1994. Of the total An. darlingi tested, none was positive for $P$. vivax-210 (95\% CI: 0-0.051\%) CS protein.

The entomological inoculation rates (EIR), calculated as the number of positive sporozoite $A n$. darlingi bites received by one person in one year for each Plasmodium species are presented in the Table. The total estimated EIR was 128.6 positive bites per person per year, i.e. approximately every three days a person may received an infective bite.

\section{DISCUSSION}

Malaria is the most common disease among the Yanomami Amerindians in the Upper Orinoco River with an API of 1279 per 1000 population, which means that people are infected by malaria parasites more than once a year. In fact, it was observed that some people suffered from the disease up to three times in one year.

Transmission occurs throughout the year with a peak during September (rainy season) when the abundance of the incriminated vector An. darlingi also peaks. A contrasting situation has been reported during a longitudinal study conducted between 1989-1991 in the western Brazilian Amazon, where although malaria transmission occurred all year round, the peak is during the dry season (June-August) (Camargo et al. 1996).

During the present study $58 \%$ of the cases were reported in children less than 10 years of age, while five cases were reported in people between $50-55$ years, and no cases were reported in people over 55. In general, the estimated ORs of the number of malaria cases and age group indicated that the risk for the age group under 10 years was $77 \%$ greater than in the group of over 50 years, suggesting a considerable degree of immunity in the later group, as indicated by Marcano et al. (2004). The large incidence in children suggests that transmission is taking place inside the house, whereas in hypoendemic areas of Rondônia, Brazil, a higher incidence was reported in young adults and transmission related to working activity outside human dwellings (Camargo et al. 1996)

It is important to point out that in this area, the most prevalent parasite was $P$. falciparum (63.8\%), while for the Amazon region of Brazil between 1993 and 1995 it was reported that $P$. falciparum infections accounted for $35.4 \%$ while for $P$. vivax was $63.8 \%$, $P$. malariae infections were less than 0.1\% (CEN, FNS 1993-1994). Much lower prevalence of $P$. falciparum and $P$. malariae was reported for the same period in the Amazonian Departments of Colombia. In fact, $P$. falciparum infections accounted for $23 \%$ of reported cases while for $P$. vivax it reached $76.6 \%$ and $0.001 \%$ for P. malariae (Unidad Administrativa Especial de Campañas Directas, Ministerio de Salud, 1993-1995). Further longitudinal studies in the same area of Ocamo conducted between 1999 and 2000 showed an increase in the prevalence of $P$. vivax (43\%) and a decrease of $P$. falciparum (48\%), while $P$. malariae recorded prevalence was about the same $(4 \%)$ (Magris et al. 2007).

In general, throughout the study, $P$. falciparum was the most prevalent parasite species (Fig. 4) with major peaks during June and September associated with larger incidence (Fig. 3). The large proportion of P.falciparum cases reported in the study area and the large sporozoite rate estimated for $P$. falciparum and $P$. malariae (Table), indicates that the sporadic vector control measures applied (fenitrothion indoor spraying) were not effective in reducing adult vector mortality and hence their expectation of life (Najera \& Zaim 2003); in this area $A n$. darlingi is living long enough for the parasite to complete its development.

The highest prevalence of $P$. malariae in the region was reported among Amerindians of the Campas ethnic group in an isolated locality (Cutiverini) along the Ene River in Southeastern Perú where $83.5 \%$ of positive 
slides were $P$. malaria; $P$. vivax accounted only for $10.1 \%$, and $5.1 \%$ were mixed $P$. malariae/ $P$. vivax infections. No P. falciparum cases were reported and entomological surveys were not carried out (Sulzer et al. 1975). Studies conducted among Amerindian populations along the Xingu River in the state of Pará, Brazil, reported high antibody responses to blood stages of $P$. malariae/P. brasilianum (56\%), P. falciparum (65\%), and $P$. vivax (76\%) (Arruda et al. 1989). An. darlingi was the predominant species collected in the Xingu River area and the only species found infected.

An. darlingi is the predominant anopheline species entering the very smoky dwellings and biting humans in Ocamo. Other species collected such as An. braziliensis and An. oswaldoi, which are more abundant and were found positive for malaria parasites in Brazil (Branquinho et al. 1996, Póvoa et al. 2001, 2006, Silva et al. 2002) and Colombia (Quiñones et al. 2006), accounted only for 7.4 and $0.2 \%$ respectively of the total number of anophelines collected.

An. darling $i$ was most abundant between July and October after the peak of the rains. Abundance was positively related with the maximum level of the Orinoco river, which is associated with larval habitats, i.e. mainly large lagoons created by overflow from the river (Rejmánková et al. 1999, Rubio-Palis et al. 2005). The correlation between rainfall and mean number of $A n$. darlingi was not significant ( $\mathrm{p}>0.5$ ). Similar observations were reported in the Peruvian Amazon, where the abundance of $A n$. darlingi decreased during the rainy season and increased after the peak of the rains (Vittor et al. 2006). Contrasting observations were reported by Hudson (1984) in the Suriname rainforest and some localities of the Peruvian Amazon in Loreto and Madre de Dios (León et al. 2003, Tineo et al. 2003), where the peak abundance of An. darlingi occurred in the middle of the rainy season when the river was at its highest. An. darlingi biting activity occurred throughout the night, with an extended peak between midnight and 5:00 a.m. A study carried out in the same village during August 1995 showed a similar biting pattern for An. darligi which was active until 7:00 a.m. (Rubio-Palis 1995). Revisions on the biting pattern of An. darlingi reported that there are geographic variations in the biting patterns (Rosa-Freitas et al. 1992, Zimmermann 1992, Rubio-Palis 2000). Nevertheless, the pattern observed in Ocamo has not been reported elsewhere. A mean man-biting rate of 40 bites/ man/night was estimated for An. darlingi during the study, much higher than the rate reported by Moreno et al. (2002) in gold mining areas of the state of Bolívar and in other countries in the region. In fact, the highest biting rate reported in the Peruvian Amazon was 4.9 bites/ man/night (Vittor et al. 2006), while in the state of Rondônia, Brazil, mean biting rates reported were 7.9 and 9.1 bites/man/night (Soares Gill et al. 2003), and in Boa Vista lower biting rates were reported (Silva-Vasconcelos et al. 2002, Póvoa et al 2006). The reported abundance of An. darlingi in this hyperendemic malaria area partly explains the high transmission rates observed.

Engorged An. darlingi were observed on different occasions during all- night landing catches or early morn- ing on screened windows of two houses, suggesting that this species leaves the houses shortly after feeding. Detailed studies are required on the indoor-outdoor resting behavior of this important vector.

$P$. falciparum was the predominant species, accounting for $64 \%$ of all infections in humans which agrees with the results of the sporozoite ELISAs. Nevertheless, we found an EIR for P. malariae (41.4), much higher than expected considering that only $4.5 \%$ of the cases reported were of this species. We have observed that in positive $P$. malariae blood slides the parasitaemia was low so that it was possible we missed some cases by only examining 100 fields. We suggest that for future routine malaria diagnosis in this area at least 200 fields should be examined. It is interesting to point out that although $P$. vivax-210 polymorph is the most frequent parasite (Rosenberg et al. 1989, Wirtz et al. 1992, Kain et al. 1992, Machado \& Póvoa 2000), none of 7295 anophelines tested were positive for this CS antigen. Nevertheless, the confidence intervals for both $P$. vivax polymorphs overlap; i.e. they are not significantly different (Table). Future studies in this area should investigate if the same is true in the human host.

In general, the positivity rate of confidence intervals for the parasite species tested overlapped (Table), so that the positivity rates are not significantly different. The high infection rates with $P$. falciparum and $P$. malariae suggest that vectors had a long life expectancy. Contrasting results were reported by Póvoa et al. (2006) from the neighboring state of Roraima, Brazil where the most common parasite identified in An. darlingi and An. albitarsis E was $P$. vivax $(70.5 \%)$ followed by $P$. falciparum $(27.3 \%)$ and $P$. malariae $(2.3 \%)$. The present study reported what is so far the highest entomological inoculation rate (129 infective bites/person/yr) in the Americas. In general, there are few studies where the EIR was estimated. In fact, in Rondônia, Soares Gil et al. (2003) reported for An. darlingi an EIR of 10 infecting bites per person per year, while in urban areas of Boa Vista (Roraima, Brazil) Silva-Vasconcelos et al. (2002) reported that the highest EIR was in An. albitarsis s.l. (6.9 infective bites/person/yr) and An. darlingi only accounted for 1.65 positive bites/person/yr. In gold mining areas of Bolivar, Venezuela, Moreno et al. (2005) found positive for $P$. falciparum and $P$. vivax $\mathrm{CS}$ protein An. darlingi, An. marajoara and An. neomaculipalpus, and estimated an overall EIR of 14 infective bites/person/yr (Moreno et al. in preparation); whereas, for An. nuneztovari, the principal malaria vector in Western Venezuela, Rubio-Palis et al. (1992) reported an EIR of 10.5 infective bites/person/yr. The EIR is an estimate of the risk of contracting malaria in a particular area, and so far in the Americas, the Upper Orinoco River is the place with a higher risk because of the high levels of $A n$. darlingi and the high rate of infection with malaria parasites although the EIR estimated for An. darlingi is considerably much lower than that reported for $A n$. gambiae and An. funestus of 540 infective bites/person/yr 540 in Tanzania (Curtis et al. 1998).

In the Upper Orinoco River, where the transmission of malaria occurs throughout the year, the high incidence 
is mainly the result of multi-drug-resistant strains of $P$. falciparum (Magris 1996, Riggione et al. 1998), the abundance and biting behavior of the incriminated vector An. darlingi with higher activity between midnight and dawn when people are sleeping, the higher risk of infection, the characteristics of the Yanomami population with its frequent migration and their shelters without walls suggested that an effective intervention to control malaria in this remote area could be by the introduction of insecticide-treated hammock nets. The present study was the basis for the introduction and evaluation of insecticide-treated hammock nets vs placebotreated nets. The study was carried out between 1999 and 2000 and reported that insecticide-treated nets prevent $55 \%$ (IRR: $0.44,95 \%$ CI: $52-59 \%$ ) of new malaria cases (Magris et al. 2007).

\section{ACKNOWLEDGMENTS}

To the Yanomami population which permitted us to do the mosquito catches in theirs "shabonos". To Clemencia González, Hernán Guzmán, and Marina García who assisted in laboratory activities. To Henry Rupp for correcting the English language. The map of the study sites was produced by Teresa Méndez. To Smith Kline Beecham for the Pf and Pv-210 positive controls, and the following laboratories that produced the MAb cell lines: New York University (Pf), Naval Medical Research Institute (Pv210), Walter Reed Army Institute of Research (Pv-247), and Centers for Disease Control, Atlanta (Pm). This study used reagents produced with support from the UNDP/WORLD BANK/ WHO Special Programme for Research and Training in Tropical Diseases. To Robert Wirtz for sending reagents and materials for the ELISAs.

\section{REFERENCES}

Arruda M, Carvalho MB, Nussezweig R, Maracic M, Ferrerira W, Cochrane AH 1986. Potential vectors of malaria and their different susceptibility to Plasmodium falciparum and Plasmodium vivax in Northern Brazil identified by immunoassay. Am J Trop Med Hyg 35: 873-881.

Arruda M, Nardin EH, Nussenzweig RS, Cochrane AH 1989. Sero-epidemiological studies of malaria in Indian tribes and monkeys of the Amazon basin of Brazil. Am J Trop Med Hyg 41: 379-385.

Branquinho MS, Araújo MS, Natal D, Marrelli MT, Rocha RM, Taveira FAL, Kloetzel JK 1996. Anopheles oswaldoi an important potential malaria vector in Acre, Brazil. Trans $R$ Soc Trop Med Hyg 90: 233.

Camargo LM, dal Colletto GM, Ferreira MU, Gurgel Sde M, Escobar AL, Marquez A, Krieger H, Canargo EP, da Silva LH 1996. Hypoendemic malaria in Rondônia (Brazil, western Amazon region): seasonal variation and risk groups in an urban locality. Am J Trop Med Hyg 55: 32-38.

Curtis CF, Maxwell CA, Finch RJ, Njunwa KJ 1998. A comparison of use of a pyrethroid either for house spraying or for bednet treatment against malaria vectors. Trop Med Intl Hlth 3: 619-631.

Deane LM 1986. Malaria vectors in Brazil. Mem Inst Oswaldo Cruz 81 (Suppl. II): 5-14.

Deane LM 1989. A cronologia da descoberta dos transmissores da malária na Amazônia Brasileira. Mem Inst Oswaldo Cruz. 84 (Suppl. IV): 149-156.
DER 1994. Dirección de Endemias Rurales, Ministerio de Sanidad y Asistencia Social. Records.

DER 1998. Dirección de Endemias Rurales, Ministerio de Sanidad y Asistencia Social. Records.

Flores-Mendoza C, Fernández R, Escobedo-Vargas KS, VelaPérez Q, Schoeler GB 2004. Natural Plasmodium infections in Anopheles darlingi and Anopheles benarrochi (Diptera: Culicidae) from Eastern Peru. J Med Entomol 41: 489-494.

Goldbrunner A 1984. El Clima en Venezuela. Atlas Climatológico, Período 1951-1970, Servicio de Meteorología, Fuerza Aérea Venezolana, Ministerio de la Defensa, Maracay, 73 pp.

Grieco JP, Achee NL, Roberts DR, Andre RG 2005. Comparative susceptibility of three species of Anopheles from Belize, Central America, to Plasmodium falciparum (NF-54). J Amer Mosq Control Assoc 21: 279-290.

Huber O 1995. System of Vegetation Classification. In JA Steyermark, PE Berry, BK Holst (eds), Flora of the Venezuelan Guayana, Vol. I, Timer Press Inc., US, p. 100-160.

Hudson J E 1984. Anopheles darlingi Root (Diptera: Culicidae) in the Suriname rain forest. Bull Entomol Res 74: 129-142.

INE-Instituto Nacional de Estadística 1993. Censo poblacional 1992.

INE-Instituto Nacional de Estadística 2001. Síntesis Estadística Amazonas, p. 1-55

Kain KC, Wirtz RA, Fernández I, Franke EI, Rodríguez MH, Lanar DE 1992. Serologic and genetic characterization of Plasmodium vivax from whole blood-impregnated filter paper disc. Am J Trop Med Hyg 46: 473-479.

Koeppen W 1948. Climatología. Sección de Obras Geografía, Editorial Fondo de Cultura Económica, México, 478 pp.

León W, Valle J, Naupay R, Tineo E, Rosas A, Palomino M 2003. Comportamiento estacional del Anopheles (Nyssorhynchus) darlingi Root 1926 en localidades de Loreto y Madre de Díos, Perú 1999-2000. Rev Peru Med Exp Salud Pública 20: 22-27.

Lizot J 1988. Los Yanomami. In Los Aborígenes de Venezuela. Etnología Contemporanea, Vol. 3, FLSMA Caracas, p. 479-697.

Lizot J 1998. Situación Cultural y Acción Sanitaria. El Caso Yanomami, Puerto Ayacucho, Venezuela, p. 1-19.

Lourenço-de-Oliveira R, Guimarães AE, Arle M, da Silva TF, Castro MG, Motta MA, Deane LM 1989. Anopheline species, some of their habits and relation to malaria in endemic areas of Rondônia State, Amazon Region of Brazil. Mem Inst Oswaldo Cruz 84: 501-514.

Machado RL, Póvoa MM 2000. Distribution of Plasmodium vivax variants (VK210, VK247 and $P$. vivax-like) in three endemic areas of the Amazon region of Brazil and their correlation with chloroquine treatment. Trans $R$ Soc Trop Med Hyg 94: 377-381.

Magris M 1996. Susceptibilidad in vitro de Plasmodium falciparum a la Cloroquina, Amodiaquina, Quinina, Mefloquina y Sulfadoxina/Pirimetamina, Ocamo, Alto Orinoco, Estado Amazonas 1994, MSc Thesis Escuela de Malarialogia-Universidad de Carabobo, 87pp.

Magris M, Rubio-Palis Y, Alexander N, Ruíz B, Galván N, Frías D, Blanco M, Lines J 2007. Community-randomized trial and 
lambdacyhalothrin-treated hammock nets for malaria control in Yanomami communities in the Amazon region of Venezuela. Trop Med Int Hlth 12: 1-12.

Marcano TJ, Morgano A, Tosta CE, Rodrigues Coura J 2004. Cross-sectional study defines difference in malaria morbidity in two Yanomami communities on Amazonian boundary between Brazil and Venezuela. Mem Inst Oswaldo Cruz 99: 369-376.

MARNR 1995. Ministerio del Ambiente y de los Recursos Naturales Renovables. Datos Climatológicos. Estación Santa Maria de los Guiacas.

Moreno JE, Rubio-Palis Y, Paez E, Pérez E, Sánchez V, Vaccari E 2005. Anopheles (Anopheles) neomaculipalpus: a new malaria vector in the Amazon basin? Med Vet Entomol 19: 329-332.

MSAS 1995. Ministerio de Sanidad y Asistencia Social. Reporte Epidemiológico.

MS 2005. Ministerio de Salud, Dirección de Salud Ambiental. Reporte Epidemiológico.

Nájera JÁ, Zaim M 2003. Malaria vector control. Decision making criteria and procedures for judicious use of insecticides. WHO/CDS/WHOPES/2002.5.

Osborn FR, Rubio-Palis Y, Herrera M, Figuera A, Moreno JE 2004. Caracterización Ecoregional de los vectores de Malaria en Venezuela. Bol Mal Sal Amb 44: 77-92.

Póvoa MM, Wirtz RA, Lacerda RNL, Miles MA; Warhurst D 2001. Malaria vectors in the municipality of Serra do Navio, state of Amapá, Amazon Region, Brazil. Mem Inst Oswaldo Cruz 96: 179-184.

Póvoa MM, de Souza RTL, Lacerda RNL, Santa Rosa E, Galiza D, Rodrigues de Souza J, Wirtz RA, Schlichting CD, Conn JE 2006. The importance of Anopheles albitarsis and An. darlingi in human malaria transmission in Boa Vista, state of Roraima, Brazil. Mem Inst Oswaldo Cruz, 101: 163-168.

Quiñones ML, Ruíz F, Calle DA, Harbach RE, Erazo HF, Linton Y 2006. Incrimination of Anopheles (Nyssorhynchus) rangeli and An. (Nys.) oswaldoi as natural vectors of Plasmodium vivax in Southern Colombia. Mem Inst Oswaldo Cruz 101: 617-623.

Rachou RG 1958. Anofelinos do Brasil: Comportamento das espécies vetoras de malária. Rev Brasil Malario Doenças Trop 10: 145-181.

Rejmánková E, Rubio-Palis Y, Villegas L 1999. Larval habitats of anopheline mosquitoes in the Upper Prinoco River, Venezuela. J Vector Ecol 24: 130-137.

Riggione F, Magris M, Serafin LM, Mijares G, Charris J, Dominguez J, Urbina J 1998. La quimiosensibilidad de Plasmodium falciparum de Venezuela. Bol Dir Malariol San Amb 38: 5-13.

Rosa-Freitas M G, Broomfield G, Priestman A, Mílligan PJ, Momen H, Molyneux D 1992. Cuticular hydrocarbons, isoenzymes and behavior of three populations of Anopheles darlingi from Brazil. J Am Mosq Control Assoc 8: 357-366.

Rosemberg R, Wirtz R A, Lanar DE, Sattabogkot J, Hall T, Waters AP, Prasittisuk C 1989. Circumsporozoíte protein heterogeneity in the human malaria parasite Plasmodium vivax. Science 245: 973-976.
Rubio-Palis Y 1995. Observaciones sobre el patrón de actividad hematofágica del vector de malaria Anopheles darlingi en poblaciones del sur de Venezuela. Bol Dir Malariol San Amb 35: 66-70.

Rubio-Palis Y 2000. Anopheles (Nyssorhynchus) de Venezuela: Taxonomía, Bionomía, Ecología e Importáncia Médica. Escuela de Malariología y Saneamiento Ambiental "Dr. Arnoldo Gabaldon" - Proyecto Control de Enfermedades Endémicas. Maracay, Venezuela, 120 pp.

Rubio-Palis Y, Zimmerman RH 1997. Ecoregional classification of malaria vectors in the neotropics. J Med Entomol 34: 499-510.

Rubio-Palis Y, Menare C, Quinto A, Magris M, Amarista M 2005. Caracterización de criaderos de anofelinos (Diptera: Culicidae) vectores de malaria del Alto Orinoco, Amazonas, Venezuela. Entomotropica 20:29-38.

Rubio-Palis Y, Wirtz RE, Curtis CF 1992. Malaria entomological rates in western Venezuela. Acta Trop 52: 167-174.

Silva-Vasconcelos A, Neves Kató MY, Neves Mourão E, Lessa de Souza RT, Luz Lacerda RN, Sibajev A, Tsouris P, Povoa MM, Momen H, Rosa-Freitas MG 2002. Biting indices, hostseeking activity and natural infection rates of anopheline species in Boa Vista, Roraima, Brazil from 1996 to 1998. Mem Inst Oswaldo Cruz 97: 151-161.

Soares Gil LH, Alves FP, Zieler H, Salcedo JMV, Durlacher RR, Cunha RPA, Tada MS, Camargo LMA, Camargo EP, Pereida-da-Silva LH 2003. Seasonal malaria transmission and variation of anopheline density in two distinct endemic areas in Brazilian Amazônia. J Med Entomol 40: 636-641.

Sulzer AJ, Cantella R, Colichon A, Gleason NH, Walls KW 1975. A focus of hyperendemic Plasmodium malariae-P. vivax with no $P$. falciparum in a primitive population of the Peruvian Amazon jungle. Bull WHO 52: 273-278.

Tadei WP, Dutary Thatcher B, Santos JMM, Scarpassa VM, Rodrigues IB, Rafael MS 1998. Ecologic observations oh anopheline vectors of malaria in the Brazilian Amazon. Am J Trop Med Hyg 59: 325-335.

Tineo E, Medina A, Fallaque C, Chávez L, Quispe S, Mercado M, Zevallos J, Leon W, Palomino M 2003. Distribución geográfica y comportamiento estacional de la picadura del Anopheles (Nyssorhynchus) darlingi Root 1926 en localidades de la frontera Perú-Bolivia, Madre de Díos, Perú. Rev Peru Med Exp Salud Pública 20: 78-83.

Vittor A, Gilman RH, Tielsch J, Glass G, Shields T, Sánchez Lozano W, Pinedo-Cancino V, Patz JA 2006. The effect of deforestation on the human-biting rate of Anopheles darlingi, the primary vector of falciparum malaria in the Peruvian Amazon. Am J Trop Med Hyg 74: 3-11.

Wirtz RA, Burkot TR, Graves PM, Andre RG 1987. Field evaluation of enzyme-linked immunosorbent assays for Plasmodium falciparum and Plasmodium vivax sporozoites in mosquitoes (Diptera: Culicidae) from Papua New Guinea. J Med Entomol 24: 433-437.

Wirtz RA, Sattabongkot J, Hall T, Burkot TR, Rosenberg R 1992. Development and evaluation of an ELISA for Plasmodium vivax-VK247 sporozoites. J Med Entomol 29: 854-857.

Zimmerman RH 1992. Ecology of malaria vectors in the Americas and future directions. Mem Inst Oswaldo Cruz 87(Suppl. III): $371-383$ 
